\title{
Chapter 6 \\ In-Vehicle Exposures at Transportation and the Health Concerns
}

\author{
Xi Fu
}

\begin{abstract}
In-vehicle environment is a special indoor environment, which is mobile, either open or closed. This chapter reviewed in-vehicle air quality and passenger exposures for roadway commuters, commercial airplanes, and marine transportation. The sources of pollutants in-vehicle can be categorized as the same as other indoor environments, including outdoor air, human activity, emission from building material and interior furnisher, and biological metabolic process from animals and microbes. However, the exposure in vehicles varies from now and then, influenced by window open/closed, speed, air flow, ventilation on/off, air conditioner on/off, pollutants from ambient outdoor air, interior material, and number of passengers. There are few studies on health condition of passengers, except infectious disease during airway transportation. Some health studies of related occupations are reviewed.
\end{abstract}

Keywords Commuters $\cdot$ Airplanes $\cdot$ Marine passenger vehicles $\cdot$ Particles Microbial community $\cdot$ VOCs

\subsection{Introduction}

As the issue of air pollution is paid more and more attention, researchers started to study environment and air quality in various specific circumstances. Indoor environment in transport vehicles is one of the specific environment. Nowadays, transportation vehicles occupy quite an amount of time in our daily life, especially for those who live in big cities. For many people in big cities in industrial countries, spending $2 \mathrm{~h}$ in commuting is a daily circumstance. Many studies were done about the environment and exposures in vehicles, and the environment in vehicles was called

\footnotetext{
X. Fu (ه)

Department of Occupational and Environmental Health, School of Public Health,

Sun Yat-sen University, Guangzhou, China

e-mail: fuxi6@mail.sysu.edu.cn
} 
"in-vehicle microenvironment," or "transport microenvironment" sometimes. According to published literature, in-vehicle exposure is generally considered to contribute at least10-20\% of daily exposure [1].

In-vehicle environment is a special indoor environment, which is mobile, and either open or closed. The sources of pollutants in-vehicle can be categorized as the same as other indoor environments, including outdoor air, human activity, emission from interior material and furnisher, and biological metabolic process from animals and microbes [1]. Comparison has been done between exposure levels with several commuter modes and roadside exposures (pavement), and different patterns have been reported. Chan et al. compared exposures from different commuting microenvironment in Hong Kong in 1990s. They reported the order of exposure from high to low: private car, the group consisting light bus, bus, tram, and roadside pavement, train, and ferry at last [2]. Moreno et al. reported a similar exposure pattern from commuters in Barcelona in 2015, in which the levels of particulate matters followed a decreasing order of diesel bus, tram, and subway. Besides, the level of $\mathrm{CO} 2$ is tripled in subway and buses of the level at pavement [3]. Moreno also reported elevated levels of $\mathrm{Mn}, \mathrm{Co}, \mathrm{Zn}, \mathrm{Sr}$, and Ba within subways and elevated levels of $\mathrm{Sb}$ and $\mathrm{Cu}$ within buses [3]. Ramos et al. have studied inhalation doses from different commuters in Lisbon in 2015, and reported highest levels of PM 10 in trams, highest levels of PM2.5 in subways, and lowest levels of particulate matters in trains and for pedestrians, considering both concentrations and ventilation rates [4].

However, the exposure in vehicles varies from now and then, influenced by window open/closed condition, driving speed, ventilation, inner air filtration, leakage airflow rate, pollutants from ambient outdoor air, interior material, and number of passengers [5].

\subsection{Commuters (Car, Tram, Bus, and Subway)}

Interior space in vehicles is small, and the air quality in vehicles is affected by window open/closed condition and the ventilation condition. Literatures have reported an air exchange rate of $120 / \mathrm{h}$ and an equilibrated exposure level to outdoor air at open window condition [6,7]. At window closed condition, in-vehicles exposure level varies upon fan on/off and air recirculation on/off [8]. Particulate matters, black carbon, NO2 are common pollutants related to outdoor air and traffic, and the level of PM2.5, black carbon, and $\mathrm{NO}_{2}$ have been reported higher in vehicles compare to ambient outdoor air [9-11]. The in-vehicle level of ultrafine particulates can be reduced by high air recirculation rate with a high efficiency air particulate filter [12]. Most of the studies on in-vehicle exposures did not include subways, and the studies on subway cabin exposure mainly focused on microbial contaminations. Roadway commuting in vehicles has been reported associated with elevated level of exhaled nitric oxide, C-reactive-protein, and exhaled malondialdehyde, which indicated inflammation in respiratory tract and increased oxidative stress [13] (Fig. 6.1). 

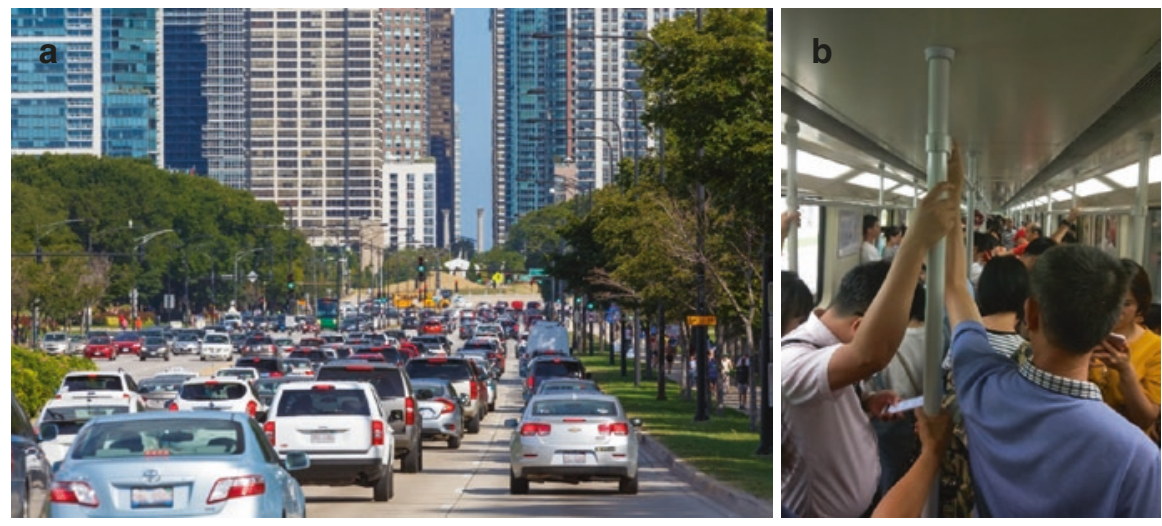

Fig. 6.1 (a) Traffic condition at rush hours on roadway. (The picture is tagged with Creative Commons licenses). (b) Peak hour condition in subway (Photo shot by Xi Fu)

\subsubsection{Paticulate Matters}

Particulate matters are one of the main kinds of pollutants from ambient outdoor air. PM2.5 and PM10 commonly exist in outdoor air. Vehicles commonly exhaust particles $<300 \mathrm{~nm}(0.3 \mu \mathrm{m})$, which contribute to the ultrafine particulate matters $(<0.1 \mu \mathrm{m})$ or PM 1 [5]. A close-window exposure measurement study in cars has reported that the concentration of particles in-vehicle is associated with ambient traffic [14]. The level of PM1-10 in vehicle was lower in the morning and higher in the evening, and the peaks of PM1 level appeared when the car was driven in busy crossroads [14].

In-car exposure to PM2.5 has been reported associated with decreased level of lymphocytes, and increased level of C-reactive protein, red blood cells, neutrophils, next-morning heart rate variability, and next-morning heart beat cycle length, which indicates that PM2.5 may cause inflammation and cardiovascular disease [15]. In-vehicle smoking increases the concentration of particulate matters, and in-vehicle second hand smoking exposure has been reported associated with current asthma [16]. Diesel-exhaust particle is one kind of main traffic pollutants, and has been detected in vehicles on roadway, contributing 30-55\% of daily exposure, which has been reported associated with pulmonary and systemic inflammation [17].

\subsubsection{VOCs}

Many kinds of VOCs have been detected in cabins of passenger vehicles, which can be emitted from interior material inside vehicle cabins, or from outdoor air by window or ventilation. Xu et al. reviewed VOCs detected in vehicle cabins, and categorized them into aromatic hydrocarbons, formaldehyde, and other carbonyl compounds 
[5]. The range of aromatic hydrocarbon level is $112-595 \mu \mathrm{g} / \mathrm{m}^{3}$, and the key compounds include benzene, toluene, ethylbenzene, and xylenes. The level of aromatic hydrocarbon pollutant increases when cabin temperature goes up, fan turned off, or air recirculation turned on [18]. Moreover, the level of benzene is one tenth higher in new vehicles compared to old ones, while the concentration of toluene, xylenes, and ethylbenzene is doubled in new vehicles compared to old ones [19].

The emission of formaldehyde and carbonyl compounds is mainly from interior material in vehicle cabin, and the exposure level increases when the temperature is high. The interior concentration of total VOC has been reported to increase from winter to summer, and the interior level in summer was far higher than the outdoor level [20]. Exposure of hexanal and nonyl aldehyde has been commonly reported in vehicle cabins. The level of nonyl aldehyde increased 12.5 -folds from moderated heat condition $\left(32.2-42.8^{\circ} \mathrm{C}\right)$ to static high heat condition $\left(47.8-62.8^{\circ} \mathrm{C}\right)$ during an experimental test [21].

\subsubsection{Inorganic Pollutants}

\section{Black Carbon}

The concentration of black carbon has been reported to be highly dynamic and associated with ambient traffic condition [22], and the level was higher on weekdays during a week, and in the morning during a day [14]. The level of black carbon in vehicles can be effected by the type of vehicles followed, which was highest when diesel-powered cars were followed, and lowest when gasoline-powered cars or not any cars were followed [23].

\section{Carbon Monoxide (CO)}

A Finnish study during 1990s reported in-vehicle CO level was 5.7 ppm during rush hours [24], and the concentration was influenced by time of day, average driving speed, wind speed, and relative air humidity. An experimental study tested health effect of different in-car $\mathrm{CO}$ exposure level, and reported the $\mathrm{CO}$ concentration was associated with decreased blood pressure, decreased concentrating conscious, and increased fatigue level [25].

\section{Nitrogen Dioxide $\left(\mathrm{NO}_{2}\right)$}

Not so many studies studied the concentration of nitrogen oxides in vehicles. Hazlehurst has reported, quite recently, the concentration of $\mathrm{NO}_{2}$ in vehicle is about six times of the ambient outdoor level, and contributed to $30 \%$ of $\mathrm{NO}_{2}$ exposure during a day [26].

\subsubsection{Microbes in Subways}

The environment in subways is different from that in vehicles on the roadway. The particulate matters and gaseous oxides are not the main concern here, and some recent studies on hygiene aspects in subways mainly focused on microbial pollutants. As the 
sequencing technology is developing rapidly, researchers turned to conduct microbiome survey in subways by the metagenomic sequencing, and the knowledge of microbial community in subways has been progressed. Hsu et al. have reported that microbes associated with human skin are dominating on subway car surfaces, including the seat, the seat back, the horizontal pole, the vertical pole, and the grip; oral, gut, and some environmental taxa are also detected from seats and touchscreens [27]. Leung et al. have compared changes in the microbial community in subway cars at peak and nonpeak commuting hours, and have reported that the skin-associated genus is largely increased in peak hours; and the abundance of these genera is positively correlated with the level of carbon dioxide [28]. Walker et al. have compared microbiome patterns in subway system across multiple cities, and the differences between cities have been reported [29]. A microbial survey of subway stations by Afshinnekoo et al. has reported that the microbial community from the station can present its history. For instance, marine-associated bacteria were detected in a hurricane-flooded station [30].

\subsection{Commercial Aircrafts (Cockpit and Cabin)}

The cockpit and cabin environment in commercial aircraft is a closed environment with a specific air compressing system. This system supplies compressed air continuously to the cockpit and cabin. The outdoor air passes the engine to get heated to $400{ }^{\circ} \mathrm{C}$ and sterile, then the air enters the compressor to get cooled and packed. The packed fresh air enters the cockpit directly, while it is mixed with $50 \%$ recirculated air before entering the cabin. The air recirculation system for the cabin contains filters for particles, including pre-filters for large particles and high efficiency particulate air (HEPA) filters. HEPA filters can remove particles with a diameter down to $0.3 \mu \mathrm{m}$ with $99.99 \%$ efficiency $[31,32]$. Many, but not all aircraft have HEPA filters. In most airplanes, there is an ozone converter before the air entering cockpit and cabin. There could be moisture condensation in the airplane, which goes into the wall construction. The wall is constructed with mineral insulation, but there is no dampness barrier in the wall.

The airplane environment is impressively featured with dry air, both in the cockpit and in the cabin. The relative air humidity is usually below $10 \%$ during cruise [33], and the temperature is in the range $22-26{ }^{\circ} \mathrm{C}[33,34]$. The concentration of $\mathrm{CO} 2$ is between 500-1000 ppm during cruise [33], which is under the recommended limit of $1000 \mathrm{ppm}$ [35]. However, during the taxi, take off, and landing phases, the level of $\mathrm{CO} 2$ could reach a higher range up to $2500 \mathrm{ppm}$. The mean NO2 level has been reported at $7 \mu \mathrm{g} / \mathrm{m}^{3}$ [33]. Nowadays, in most of the airliners there is an ozone converter, which catalyze ozone into oxygen. However, it is optional on some type of airplanes. The old converters should be replaced with new ones after a certain period, otherwise the ozone level would be elevated [36]. The mean concentration of ozone in the cockpit has been reported at $26.3 \mu \mathrm{g} / \mathrm{m}^{3}$, but the highest level tested is $76.1 \mu \mathrm{g} / \mathrm{m}^{3}$ [33]. The ventilation air flow in the cockpit environment is $60-80 \mathrm{~L} / \mathrm{s}$ per person [37, 38]. There is no dampness barrier in the airplane wall, and moisture in the cabin air may enter the double-layer wall and condense, where there is a potential for bacteria and fungi growth. Radiation exposure has been evaluated among Germen aircrews, 

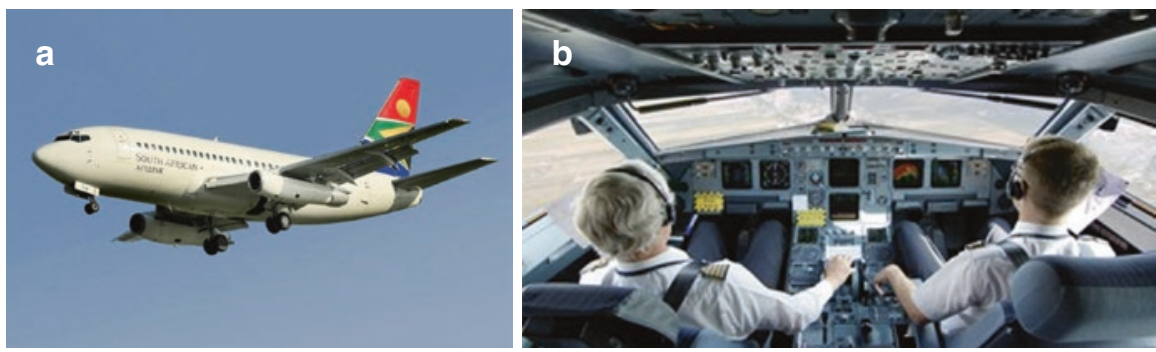

Fig. 6.2 (a) A commercial airplane on cruise. (b) Two pilots in the cockpit of a commercial airplane. (The pictures are tagged with Creative Commons licenses)

and the annual accumulative dose was reported higher in elder pilots and younger cabin crews than in their counterparts, which is associated with high frequency of long-haul intercontinental routes, mostly to the north [39] (Fig. 6.2).

\subsubsection{VOCs}

VOC exposure studies have been done in the cockpit and cabin. The level of formaldehyde in the cockpit has been reported under detection limit $\left(<5 \mu \mathrm{g} / \mathrm{m}^{3}\right)$ [33]. Sources of VOCs in the cockpit include jet oil leaked by the engine [40-42]. Various chemicals are detected in the cabin environment. Compounds in the turbine and engine oil, tricresyl phosphate are detected in both wipe samples in the aircraft and samples from the HEPA filter [43]. Brominated flame retardants (BFR) have been detected in serum of pilots, cabin crew, and aircraft maintenance workers [44], which are used for fire safety in the air plane. Moreover, compounds originated from hydraulic oil, like dibutylphenyl phosphate and tri-n-butyl phosphate, which are emitted from vehicles on the ground, have been detected in the airplane environment [43]. Levels of VOCs have been evaluated in the cabin environment in Airbus airplanes, and most VOCs are under the detection limit [45]. Studies have reported concentrations of main compounds in the cabins in Airbus airplanes, though in different units: ethanol $593 \mu \mathrm{g} / \mathrm{m}^{3}$, acetone $24 \mu \mathrm{g} / \mathrm{m}^{3}$, toluene $8 \mu \mathrm{g} / \mathrm{m}^{3}$, formaldehyde $5.7-7 \mu \mathrm{g} / \mathrm{m}^{3}$, acetic acid $6 \mu \mathrm{g} / \mathrm{m}^{3}$, and nicotine $2 \mu \mathrm{g} / \mathrm{m}^{3}$, acetaldehyde $6.5 \mu \mathrm{g} / \mathrm{m}^{3}$, and mostly very low concentrations of other aldehydes [45, 46] (Fig. 6.3).

\subsubsection{Microbes and Microbial Compounds}

Airborne bacteria exist in the cabin environment, due to passenger activity and high occupant density. The concentration of viable bacteria increases during cruise, possibly due to more frequent passenger and cabin crew activity [47]. A study using cultivating method reports that bacteria measured in the cabin environment include bacteria common on human skin surface or in dust and outdoor air [48]. Fungi levels are low, and the predominating genera include Cladosporium, Aspergillus, and 

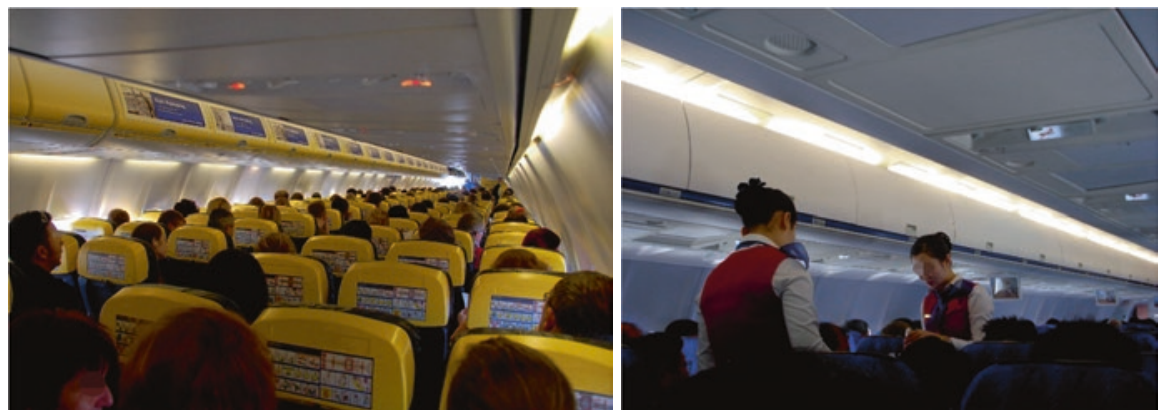

Fig. 6.3 Cabin environment of commercial airplanes (The pictures are tagged with Creative Commons licenses)

Penicillium [49]. The cultivating method is very practical, but it may lose majority of the species [47]. In recent years, sequencing of 16S rRNA gene is used to identify microbial community in a certain environment. A recent study analyzed bacterial communities in HEPA filters from commercial aircraft cabin, by microarray sequencing of 16S rRNA gene and bio-informatics analysis [50]. The subfamilies detected in airplane cabin include bacteria from human skin, gastrointestinal tracts, respiratory tracts, and bacteria from water and soil. The bacterial composition in aircraft cabin differs from urban outdoor air [50]. Pathogens as well as nonpathogens were detected [50]. A quite recent study on airplane cabin microbial community has reported that microbial diversity varies between flights; airborne microbial communities differ from those on the touch surfaces. And no patterns have been determined for the changes of microbiome community from pre- and post-flight [51]. There are few studies done on fungi levels in aircraft measured by molecular methods. Fu et al. have investigated the level of fungal DNA in the airplane environment, and have reported that the level of fungal DNA in airplanes is as low as $20 \%$ of the average level in European classrooms [52]. Microbial volatile organic compounds (MVOCs) have been detected in the airplane cabin in the same study, and the total MVOCs level has been 3.7 times of the average level in Nordic homes. Moreover, two pentanols, 2-methyl-1-butanol and 3-methyl-1-butanol, had a concentration at 15 and 17 times of the Nordic home level, respectively [52]. Endotoxin has been detected both in air and dust in the airplane cabin, and the mean endotoxin levels in air and settled dust are both higher than the mean levels reported in homes and office buildings [53]. Moreover, 3-hydroxy fatty acids, a marker of endotoxin, can be detected in settled seat dust and carpet dust [53].

\subsubsection{Viruses}

HEPA filters have a high efficiency to remove particles and microbes with a diameter larger than $0.3 \mu \mathrm{m}$ with $99.99 \%$ efficiency [54]. Fragment of bacteria and fungi $(0.1-1.0 \mu \mathrm{m})$, and viruses $(0.01-0.02 \mu \mathrm{m})$ may not be removed by the HEPA filter. 
The aircraft cabin is a crowded indoor environment and there has been concern about the spread of airway infections in aircraft. Nowadays pilots spend all time in the cockpit which has a separate ventilation system. However, before the 11th September terrorist attack in 2001, pilots could spend short periods in the forward part of the cabin during cruise, socializing with the cabin attendants. Existing studies on spread of infections in aircraft have mainly focused on transmission among passengers and airline crews. Airborne pathogen transmission was reported to be associated with sitting within two rows of the index person on board during more than $8 \mathrm{~h}$ [55]. The transmission is believed to be by large droplets, and increased ventilation rate can decrease the infection risk [55]. Spread of influenza follows previously observed transmission model, but passengers sitting further away than two rows can be infected [55]. Transmission of severe acute respiratory syndrome (SARS) can occur on board faster and at wider areas than the typical transmission model [56]. One tracing contact study of SARS among 1766 passengers found no spread of SARS [57]. Another study of SARS infection traced 304 passengers and crew with one or two index person on board, and reported 23 infections [56]. The relative risk of passengers sitting within three rows in front of the index person was 3.1 (95\% CI: 1.4-6.9), compared to passengers seated elsewhere in the cabin [56]. Two tracing contact studies of the swine-origin influenza A (H1N1) pdm09 from UK and USA have reported an attack rate of $4.3 \%(95 \%$ CI: $1.7-6.9 \%$ ) [58] and 5.2\% [59], respectively, among passengers from flights carrying one index passenger, but no crew got infected [59]. The transmission during air travel is a common concern, since it contributes to intercontinental spread of pathogens.

\subsubsection{Allergens}

Aircraft cabin is a high density public indoor environment, and pet keepers may bring allergens on board. There are very few studies on pet allergen levels on board commercial aircraft. A New Zealand study has reported that, in domestic commercial aircraft cabin, cat allergen (Fel d1) level is higher on the seats than on the floor [60]. In some airlines, passengers are allowed to bring small furry pets with them, which increases the risk of allergen contamination on board. Fu et al. have reported that textile material used in cabin seats is associated with higher dust amount and higher allergen levels in the cabin when compared with leather seats. The levels of cat (Fel d1), dog (Can f1), and horse (Equ cx) allergens in the cabins with textile seats are 50, 27, and 75 times of those levels in cabins with leather seats, respectively [52]. 


\subsubsection{Occupational Health Studies in Pilots}

There are not so many studies on passenger health except the infections mentioned above. Some occupational health studies among commercial pilots have been conducted. Eye symptoms, nose symptoms, and tiredness have been commonly reported by Swedish commercial pilots, with a prevalence at $38.5 \%, 39.9 \%$, and $29.9 \%$, respectively [61]. The incidence of doctor diagnosed asthma among Swedish commercial pilots is 2.4 per 1000 person years, which is slightly higher than the general population in Europe. Besides, the incidence of atopy among those pilots is 16.6 per person years [62].

\subsection{Marine Passenger Vehicles (Cruise Ships/Ferries/ Passenger Cargo Vessels)}

There are not so many studies about indoor air quality in cabins of passenger ships. Some studies reported emissions from ferry or ship engine exhaust, which elevated the level of $\mathrm{CO}_{2}$ and $\mathrm{NO}_{\mathrm{x}}$ by threefold on average, and the levels of VOCs vary a lot when different kinds of fuel and fuel load were used [63]. Webster and Reynolds reviewed studies on indoor air quality on passenger ships, including effective factors, sources of pollutants, levels of pollutants, and health concerns [64]. The main pollutants from traffic pollution, like NOx, $\mathrm{CO}$, and VOCs have been reported at low level in indoor environment on these ships/ferries, and the indoor air quality is affected by heating, ventilation, and air conditioning (HVAC) system. According to reported data, the indoor air quality of cabin rooms is relatively stable, while the indoor air condition varies time by time in bars and restaurants, depending on the number of customers. The average temperature and relative air humidity in cabin rooms are $22{ }^{\circ} \mathrm{C}$ and $30 \%$, respectively, and the concentration of $\mathrm{CO}_{2}$ is in the range 600-800 ppm when there is human activity. Moreover, the average temperature and relative air humidity in bars and restaurants are $20{ }^{\circ} \mathrm{C}$ and $40 \%$, respectively, and the concentration of $\mathrm{CO}_{2}$ is in the range 600-1500 ppm when there is human activity [65] (Fig. 6.4).

Microbes (biological contaminants) have been reported to be the main contaminants in indoor environment on passenger ships. There are usually filters in ventilation system to block particles and microbes, from entering the indoor air on board. However, dirty, old, or damaged filters very often allowed spores of mould passing through and entering the indoor air [65]. Cladosporium, Penicillium, and Aspergillus have been detected on board passenger ships, which are commonly detected in indoor or outdoor moulds [65]. Aspergillus may cause health problems among people with a weak immune system or lung disease, or in combination with other bacteria or fungi [66]. No quantified levels of microbial contamination have been reported (Fig. 6.5). 

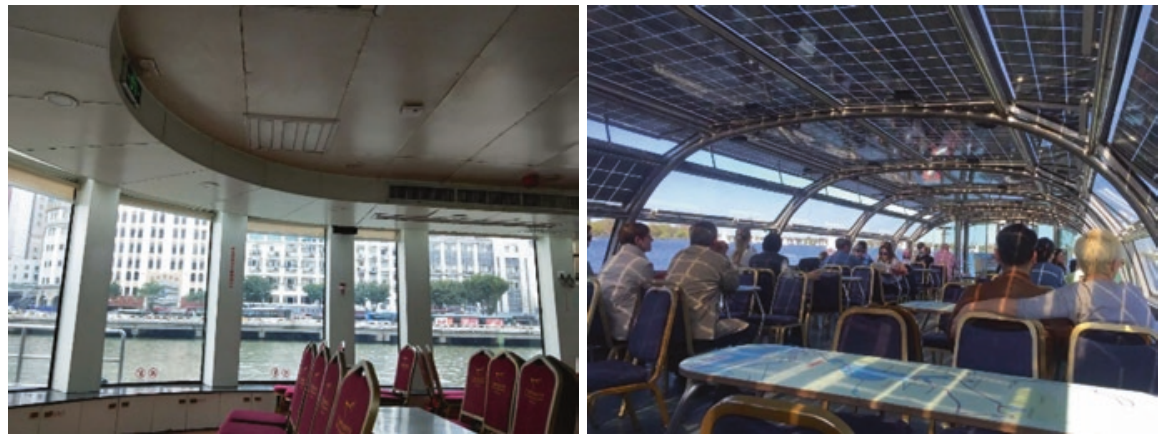

Fig. 6.4 Cabin environment of ferries (Photos shot by Xi Fu)
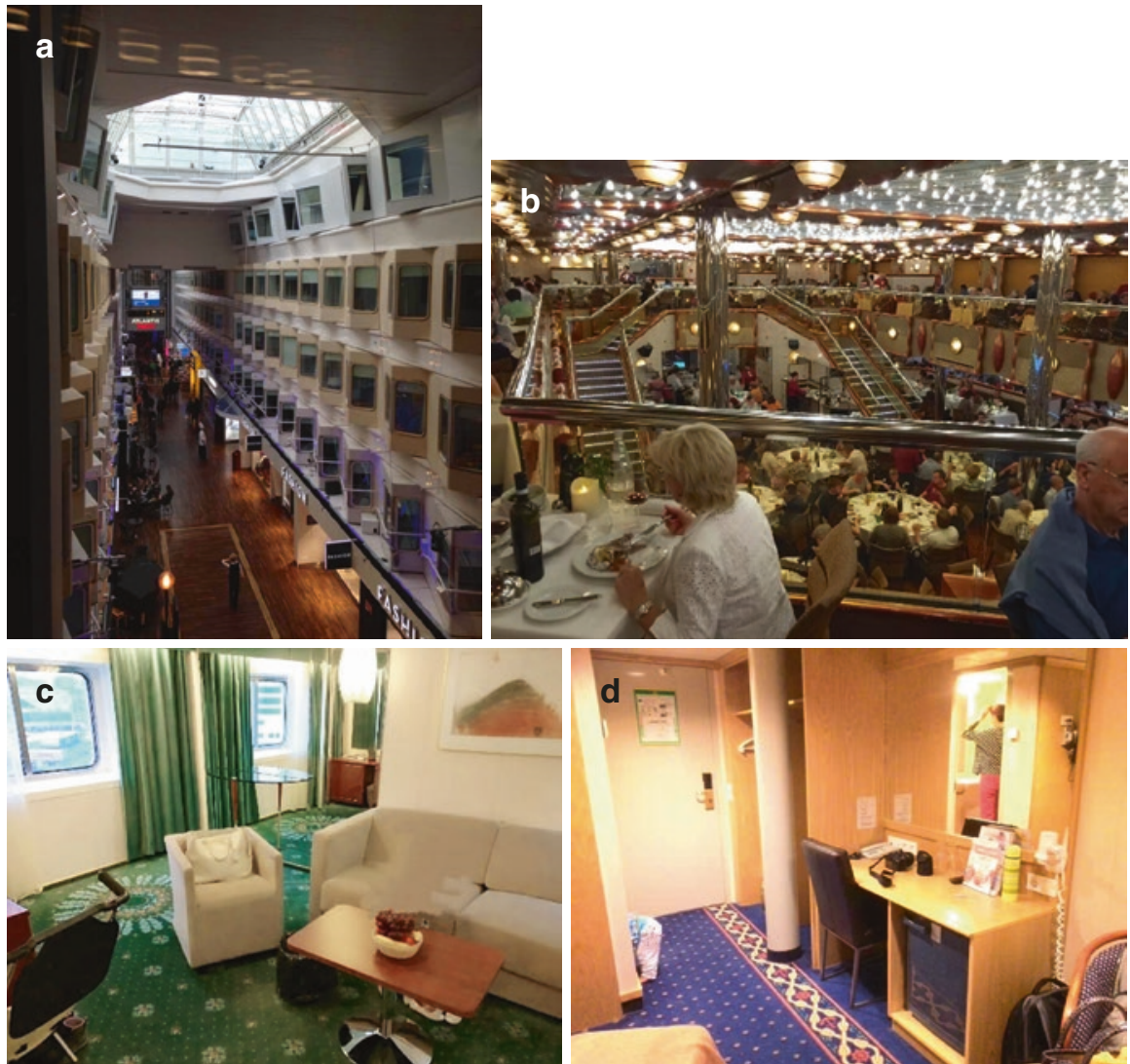

Fig. 6.5 Various indoor environment on cruise ships. (a) Shopping area; (b) a large dining room; (c, d) cabin rooms (Photos shot by $\mathrm{Xi} \mathrm{Fu)}$ 


\subsection{Conclusion}

Transportation vehicles play an important role in people's daily life nowadays. Vehicles in various ways have different features and main pollutants in interior environment. Particles and traffic-related pollutants are main concern for commuters in cities, and these pollutants may cause inflammations, and increase risks for cardiovascular diseases. The airplane cockpit and cabin environment are featured with low relative air humidity, and the cabins with textile seats are concerned with furry pet allergen contaminations. For the passenger ships, microbial contamination has been the main concern. There are lack of health studies of passengers related to in-vehicle exposures for airway and marine transport. Further studies are needed to investigate the health risk factors in in-vehicle environment.

\section{References}

1. Liu X, Frey HC. Modeling of in-vehicle human exposure to ambient fine particulate matter. Atmos Environ. 2011;45(27):4745-52.

2. Chan LY, Chan CY, Qin Y. The effect of commuting microenvironment on commuter exposures to vehicular emission in Hong Kong. Atmos Environ. 1999;33(11):1777-87.

3. Moreno T, Reche C, Rivas I, Cruz Minguillón M, Martins V, Vargas C, et al. Urban air quality comparison for bus, tram, subway and pedestrian commutes in Barcelona. Environ Res. 2015;142:495-510.

4. Ramos MJ, Vasconcelos A, Faria M. Comparison of particulate matter inhalation for users of different transport modes in Lisbon. Transp Res Procedia. 2015;10:433-42.

5. Xu B, Chen X, Xiong J. Air quality inside motor vehicles' cabins: a review. Indoor Built Environ. 2016;27(4):452-65.

6. Ott W, Switzer P, Willits N. Carbon monoxide exposures inside an automobile traveling on an urban arterial highway. Air Waste. 1994;44(8):1010-8.

7. Park JH, Spengler JD, Yoon DW, Dumyahn T, Lee K, Ozkaynak H. Measurement of air exchange rate of stationary vehicles and estimation of in-vehicle exposure. J Expo Anal Environ Epidemiol. 1998;8(1):65-78.

8. Xu B, Zhu Y. Quantitative analysis of the parameters affecting in-cabin to on-roadway (I/O) ultrafine particle concentration ratios. Aerosol Sci Technol. 2009;43(5):400-10.

9. Morales Betancourt R, Galvis B, Balachandran S, Ramos-Bonilla JP, Sarmiento OL, GalloMurcia SM, et al. Exposure to fine particulate, black carbon, and particle number concentration in transportation microenvironments. Atmos Environ. 2017;157:135-45.

10. Joshua SA, Thomas WK, Alexander HR, Shyam JD, Geetanjali K, Arvind C, et al. Concentrations of fine, ultrafine, and black carbon particles in auto-rickshaws in New Delhi, India. Atmos Environ. 2011;45(26):4470-80.

11. Weichenthal S, Van Ryswyk K, Kulka R, Sun L, Wallace L, Joseph L. In-vehicle exposures to particulate air pollution in Canadian metropolitan areas: the urban transportation exposure study. Environ Sci Technol. 2015;49(1):597-605.

12. Xu B, Zhu Y. Investigation on lowering commuters' in-cabin exposure to ultrafine particles. Transp Res Part D: Transp Environ. 2013;18:122-30.

13. Sarnat JA, Golan R, Greenwald R, Raysoni AU, Kewada P, Winquist A, et al. Exposure to traffic pollution, acute inflammation and autonomic response in a panel of car commuters. Environ Res. 2014;133:66-76. 
14. Lee K, Sohn H, Putti K. In-vehicle exposures to particulate matter and black carbon. J Air Waste Manag Assoc. 2010;60(2):130-6.

15. Riediker M, Cascio WE, Griggs TR, Herbst MC, Bromberg PA, Neas L, et al. Particulate matter exposure in cars is associated with cardiovascular effects in healthy young men. Am J Respir Crit Care Med. 2004;169(8):934-40.

16. Nguyen KH, King BA, Dube SR. Association between current asthma and secondhand smoke exposure in vehicles among adults living in four US states. Tob Control. 2015;24(4):376.

17. Laumbach RJ, Kipen HM. Acute effects of motor vehicle traffic-related air pollution exposures on measures of oxidative stress in human airways. Ann N Y Acad Sci. 2010;1203:107-12.

18. Xiong J, Yang T, Tan J, Li L, Ge Y. Characterization of VOC emission from materials in vehicular environment at varied temperatures: correlation development and validation. PLoS One. 2015;10(10):e0140081.

19. Xu B, Wu Y, Gong Y, Wu S, Wu X, Zhu S, et al. Investigation of volatile organic compounds exposure inside vehicle cabins in China. Atmos Pollut Res. 2016;7(2):215-20.

20. Yoshida T, Matsunaga I. A case study on identification of airborne organic compounds and time courses of their concentrations in the cabin of a new car for private use. Environ Int. 2006;32(1):58-79.

21. Fedoruk MJ, Kerger BD. Measurement of volatile organic compounds inside automobiles. J Expo Anal Environ Epidemiol. 2003;13(1):31-41.

22. Dekoninck L, Int Panis L. A high resolution spatiotemporal model for in-vehicle black carbon exposure: quantifying the in-vehicle exposure reduction due to the euro 5 particulate matter standard legislation. Atmos. 2017;8(11):230.

23. Fruin SA, Winer AM, Rodes CE. Black carbon concentrations in California vehicles and estimation of in-vehicle diesel exhaust particulate matter exposures. Atmos Environ. 2004;38(25):4123-33.

24. Alm S, Jantunen MJ, Vartiainen M. Urban commuter exposure to particle matter and carbon monoxide inside an automobile. J Expo Anal Environ Epidemiol. 1999;9(3):237-44.

25. Lee GW, Bae MJ, Yang JY, Son JW, Cho JL, Lee SG, et al. Decreased blood pressure associated with in-vehicle exposure to carbon monoxide in Korean volunteers. Environ Health Prev Med. 2017;22(1):34.

26. Hazlehurst MF, Spalt EW, Nicholas TP, Curl CL, Davey ME, Burke GL, et al. Contribution of the in-vehicle microenvironment to individual ambient-source nitrogen dioxide exposure: the multi-ethnic study of atherosclerosis and air pollution. J Expo Sci Environ Epidemiol. 2018;28(4):371-80.

27. Hsu T, Joice R, Vallarino J, Abu-Ali G, Hartmann EM, Shafquat A, et al. Urban transit system microbial communities differ by surface type and interaction with humans and the environment. mSystems. 2016;1(3):e00018-16.

28. Leung MH, Wilkins D, Li EK, Kong FK, Lee PK. Indoor-air microbiome in an urban subway network: diversity and dynamics. Appl Environ Microbiol. 2014;80(21):6760-70.

29. Walker AR, Grimes TL, Datta S, Datta S. Unraveling bacterial fingerprints of city subways from microbiome 16S gene profiles. Biol Direct. 2018;13(1):10.

30. Afshinnekoo E, Meydan C, Chowdhury S, Jaroudi D, Boyer C, Bernstein N, et al. Geospatial resolution of human and bacterial diversity with city-scale metagenomics. Cell Syst. 2015;1(1):72-87.

31. Joint Aviation Authorities. Joint aviation requirements. Cosmic radiation. 2001. JAR OPS 1.309 .

32. European Committee for Standardization. High efficiency air filters (HEPA and ULPA)-Part 1: classification, performance testing, marking. EN1822-1. Brussels; 1998.

33. Lindgren T, Norback D. Cabin air quality: indoor pollutants and climate during intercontinental flights with and without tobacco smoking. Indoor Air. 2002;12(4):263-72.

34. Norback D, Lindgren T, Wieslander G. Changes in ocular and nasal signs and symptoms among air crew in relation to air humidification on intercontinental flights. Scand J Work Environ Health. 2006;32(2):138-44. 
35. ASHRAE. Ventilation for acceptable indoor air quality. Atlanta: American Society of Heating RaA-CE; 2003.

36. Weisel C, Weschler CJ, Mohan K, Vallarino J, Spengler JD. Ozone and ozone byproducts in the cabins of commercial aircraft. Environ Sci Technol. 2013;47(9):4711-7.

37. Lindgren T, Andersson K, Norback D. Perception of cockpit environment among pilots on commercial aircraft. Aviat Space Environ Med. 2006;77(8):832-7.

38. Martinez I. Aircraft environmental control. 2015. http://webserver.dmt.upm.es/ isidoro/tc3/ Aircraft\%20ECS.pdf.

39. Frasch G, Kammerer L, Karofsky R, Schlosser A, Stegemann R. Radiation exposure of German aircraft crews under the impact of solar cycle 23 and airline business factors. Health Phys. 2014;107(6):542-54.

40. van Netten C. Analysis and implications of aircraft disinsectants. Sci Total Environ. 2002;293(1-3):257-62.

41. van Netten C, Leung V. Hydraulic fluids and jet engine oil: pyrolysis and aircraft air quality. Arch Environ Health. 2001;56(2):181-6.

42. Winder C, Balouet JC. The toxicity of commercial jet oils. Environ Res. 2002;89(2):146-64.

43. Solbu K, Daae HL, Olsen R, Thorud S, Ellingsen DG, Lindgren T, et al. Organophosphates in aircraft cabin and cockpit air--method development and measurements of contaminants. J Environ Monit. 2011;13(5):1393-403.

44. Strid A, Smedje G, Athanassiadis I, Lindgren T, Lundgren H, Jakobsson K, et al. Brominated flame retardant exposure of aircraft personnel. Chemosphere. 2014;116:83-90.

45. Dechow M, Sohn H, Steinhanses J. Concentrations of selected contaminants in cabin air of airbus aircrafts. Chemosphere. 1997;35(1):21-31.

46. Rosenberger W, Beckmann B, Wrbitzky R. Airborne aldehydes in cabin-air of commercial aircraft: measurement by HPLC with UV absorbance detection of 2,4-dinitrophenylhydrazones. J Chromatogr B Analyt Technol Biomed Life Sci. 2016;1019:117-27.

47. Osman S, La Duc MT, Dekas A, Newcombe D, Venkateswaran K. Microbial burden and diversity of commercial airline cabin air during short and long durations of travel. ISME J. 2008;2(5):482-97.

48. McKernan LT, Wallingford KM, Hein MJ, Burge H, Rogers CA, Herrick R. Monitoring microbial populations on wide-body commercial passenger aircraft. Ann Occup Hyg. 2008;52(2):139-49.

49. McKernan LT, Burge H, Wallingford KM, Hein MJ, Herrick R. Evaluating fungal populations by genera/species on wide body commercial passenger aircraft and in airport terminals. Ann Occup Hyg. 2007;51(3):281-91.

50. Korves T, Piceno Y, Tom L, Desantis T, Jones B, Andersen G, et al. Bacterial communities in commercial aircraft high-efficiency particulate air (HEPA) filters assessed by PhyloChip analysis. Indoor Air. 2013;23(1):50-61.

51. Weiss H, Hertzberg VS, Dupont C, Espinoza JL, Levy S, Nelson K, et al. The airplane cabin microbiome. Microb Ecol. 2019;77(1):87-95.

52. Fu X, Lindgren T, Guo M, Cai GH, Lundgren H, Norback D. Furry pet allergens, fungal DNA and microbial volatile organic compounds (MVOCs) in the commercial aircraft cabin environment. Environ Sci: Processes Impacts. 2013;15(6):1228-34.

53. Hines CJ, Waters MA, Larsson L, Petersen MR, Saraf A, Milton DK. Characterization of endotoxin and 3-hydroxy fatty acid levels in air and settled dust from commercial aircraft cabins. Indoor Air. 2003;13(2):166-73.

54. Hocking MB, Hocking D. Air quality in airplane cabins and similar enclosed spaces. Berlin: Springer; 2005.

55. Mangili A, Gendreau MA. Transmission of infectious diseases during commercial air travel. Lancet. 2005;365(9463):989-96.

56. Olsen SJ, Chang HL, Cheung TY, Tang AF, Fisk TL, Ooi SP, et al. Transmission of the severe acute respiratory syndrome on aircraft. N Engl J Med. 2003;349(25):2416-22. 
57. Vogt TM, Guerra MA, Flagg EW, Ksiazek TG, Lowther SA, Arguin PM. Risk of severe acute respiratory syndrome-associated coronavirus transmission aboard commercial aircraft. J Travel Med. 2006;13(5):268-72.

58. Young N, Pebody R, Smith G, Olowokure B, Shankar G, Hoschler K, et al. International flightrelated transmission of pandemic influenza $\mathrm{A}(\mathrm{H} 1 \mathrm{~N} 1)$ pdm09: an historical cohort study of the first identified cases in the United Kingdom. Influenza Other Respir Viruses. 2014;8(1):66-73.

59. Neatherlin J, Cramer EH, Dubray C, Marienau KJ, Russell M, Sun H, et al. Influenza A(H1N1) pdm09 during air travel. Travel Med Infect Dis. 2013;11(2):110-8.

60. Martin IR, Wickens K, Patchett K, Kent R, Fitzharris P, Siebers R, et al. Cat allergen levels in public places in New Zealand. N Z Med J. 1998;111(1074):356-8.

61. Fu X, Lindgren T, Norback D. Medical symptoms among pilots associated with work and home environments: a 3-year cohort study. Aerosp Med Hum Perform. 2015;86(5):458-65.

62. Fu X, Lindgren T, Wieslander G, Janson C, Norback D. Respiratory illness and allergy related to work and home environment among commercial pilots. PLoS One. 2016;11(10):e0164954.

63. Jayaram V, Agrawal H, Welch WA, Miller JW, Cocker DR 3rd. Real-time gaseous, PM and ultrafine particle emissions from a modern marine engine operating on biodiesel. Environ Sci Technol. 2011;45(6):2286-92.

64. Webster A, Reynolds G. Indoor Air Quality on Passenger Ships. In: Hocking M, editor. Air Quality in Airplane Cabins and Similar Enclosed Spaces. The Handbook of Environmental Chemistry, vol. 4H. Berlin: Springer; 2005. p. 335-49.

65 . Webster AD. The contribution of ventilation system design and maintenance to air quality on passenger ships. London: The Institute of Marine Engineers; 1997. p. 145-59.

66. World Health Organization. WHO guidelines for indoor air quality: dampness and mould. Geneva: WHO; 2009. 